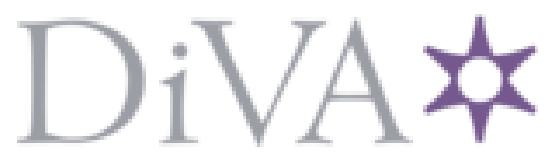

http://www.diva-portal.org

\title{
Postprint
}

This is the accepted version of a paper published in Journal of Cleaner Production. This paper has been peer-reviewed but does not include the final publisher proof-corrections or journal pagination.

Citation for the original published paper (version of record):

Missimer, M., Robèrt, K-H., Broman, G. (2016)

A Strategic Approach to Social Sustainability -Part 1: Exploring the Social System.

Journal of Cleaner Production

http://dx.doi.org/10.1016/j.jclepro.2016.03.170

Access to the published version may require subscription.

N.B. When citing this work, cite the original published paper.

Permanent link to this version:

http://urn.kb.se/resolve?urn=urn:nbn:se:bth-1 1906 


\section{A Strategic Approach to Social Sustainability - Part 1: Exploring the Social System}

This is an accepted manuscript of the article.

Please cite the article as: Missimer, M., et al., A strategic approach to social

sustainability part 1: exploring the social system, Journal of Cleaner Production (2016), http://dx.doi.org/10.1016/j.jclepro.2016.03.170

(C) 2016. This manuscript version is made available under the CC-BY-NC-ND 4.0

license http://creativecommons.org/licenses/by-nc-nd/4.0/ 


\title{
A Strategic Approach to Social Sustainability - Part 1: Exploring the Social System
}

\author{
Merlina Missimer \\ PhD, Blekinge Institute of Technology, Sweden. \\ mis@bth.se,Corresponding author \\ Karl-Henrik Robèrt \\ Professor, Blekinge Institute of Technology, Sweden \\ khr@bth.se \\ Göran Broman \\ Professor, Blekinge Institute of Technology, Sweden \\ gbr@bth.se
}

\begin{abstract}
The vast and growing array of concepts, methods and tools in the sustainability field imply a need for a structuring and coordinating framework, including a unifying and operational definition of sustainability. One attempt at such framework began over 25 years ago and is now widely known as the Framework for Strategic Sustainable Development. However, as with the larger sustainability field, the social dimension of this framework has been found to not be sufficiently science-based and operational and thus in need of further development. In this two-part series an attempt at a sciencebased, operational definition of social sustainability is presented. In this paper (part one), a systems-based approach to the social system is presented, as a basis for presenting a zero-hypothesis of principles for social sustainability in part two. Extensive literature studies as well as conceptual modeling sessions were performed and the social system was examined from various angles - complex adaptive system studies, human needs theory and other social sciences, and insights from these fields were woven together. The whole work was structured and guided by the Framework for Strategic Sustainable Development. The focus of the study was on the essential aspects of the social system that need to be sustained (that cannot be systematically degraded) for it to be possible for people to meet their needs. These essential aspects were found to be trust, common meaning, diversity, capacity for learning and capacity for self-organization. Trust seems to be generally acknowledged to be the overriding aspect of a vital social system. A sense of common meaning is also stated by several authors as an important part of social capital and something that helps to keep a group or society together. Diversity is acknowledged as essential for resilience; in the human social system this can be interpreted as, e.g., diversity of personalities, ages, gender, skills. Capacity for learning and self-organization are also motivated from a resilience point of view by several authors. These results form a basis for the hypothesis for a definition of social sustainability presented in paper 2 , which in turn is a step towards creating an enhanced support for strategic planning and innovation for sustainability.
\end{abstract}

Keywords: strategic sustainable development; social sustainability; social system; systems thinking; sustainability principles. 


\section{Introduction}

Sustainable development (SD) most prominently entered the global political arena in 1987 in a report from the United Nations Commission on Environment and Development, also known as the Brundtland report. The report stated "Humanity has the ability to make development sustainable - to ensure that it meets the needs of the present without compromising the ability of future generations to meet their own needs" (World Commission on Environment and Development 1987). In 2015, the world further solidified its commitment to SD with the 2030 Agenda for Sustainable Development (United Nations, 2015). In the almost 30 years in between, the field of SD has grown steadily (Hull 2008, Kajikawa et al. 2014). Today, there is a vast array of definitions, terms, approaches, concepts, methods and tools, many designed for specific fields only. For overviews, see the papers by Hopwood et el. (2005), Glavik and Lukman (2007), Lozano (2008), Ben-Eli (2012), Chasin (2014), and Amini and Bienstock (2014).

The concepts of SD and sustainability have been much criticized, mainly in relation to the vagueness of what sustainability and sustainable development actually mean (e.g., Jacobs 1999, McKenzie 2004, Madsen et al. 2010, Ben-Eli 2012). Ben-Eli (2012, np) considers sustainability "a term whose meaning has been watered down to the point of trivialization." Jacobs $(1999,24)$ further argues that, "the vagueness of the definition ... allows business and 'development' interests (and their government supporters) to claim that they are in favour of sustainable development when actually they are the perpetrators of unsustainability". In addition, the many different concepts, methods and tools that exist make the field difficult to navigate and can lead to confusion about how to really approach sustainability. Many in the field point to a growing need for a clearer and more operational definition and an understanding of how the existing definitions, terms, approaches, concepts, methods and tools relate to each other and can be combined in the best way to support more effective transitions towards sustainability (Huesemann 2001, Robèrt et al. 2002, Jonhnston et al. 2007, Marsden et al. 2010).

\subsection{Framework for Strategic Sustainable Development}

In response to the vagueness and lack of clarity in the general sustainability field, and in order to create a unifying structure for strategic sustainability work, some scientists have explored the possibility to develop a framework that would be helpful in this regard. This is widely known as the Framework for Strategic Sustainable Development (FSSD) (Broman and Robèrt, in this issue). It has been designed to give guidance on how any region, organization or project can develop a vision framed by principles for social and ecological sustainability, analyze and assess the current situation in relation to that vision and thus clarify the gap, generate ideas for possible actions that could help to bridge the gap, and prioritize such actions into a step-wise and economically attractive plan, thereby also supporting society's transition towards social and ecological sustainability. The approach is built on the combination of a few core tenants.

The FSSD focuses on taking a broad, systems perspective of the sustainability challenge. As the socio-ecological system is a complex adaptive system and the sustainability issues are inextricably interlinked, it is hard to predict in detail what will happen. A strategic approach therefore requires taking the whole system into account 
when creating solutions, as opposed to tackling discrete problems, one by one, as they appear, so as to not cause negative impacts somewhere else or for other people.

The FSSD also emphasizes a scientific understanding of the systems as the sustainability challenge cannot be understood without the data, experimentation, and overall knowledge about the socio-ecological system that science provides and because science in its broadest sense is the only language for systematic thinking that is accepted across national and cultural boundaries.

It uses a principle-based definition of 'Success'. First, in order to plan strategically, one needs a clear definition of the goal. It is helpful to define sustainability at a principle level because (1) it can be difficult for large groups to agree on details (due to differences in e.g. values or backgrounds); (2) many things could change (e.g. technology) resulting in a different future situation which makes scenario based goals obsolete; (3) There can be uncertainty about whether the scenario is actually sustainable; and (4) because this high-level definition allows for non-prescriptive creativity within robust constraints and also facilitates comparison and exchange of experiences between different efforts.

In the context of sustainability, success is defined as stopping the unsustainable actions that are currently threatening the socio-ecological system. Therefore, it is important to understand the basic mechanisms by which humans systematically destroy the socioecological system. The sustainability principles act as constraints within which humanity must operate in order to be socially and ecologically sustainable and can thus be used as constraints for re-design.

In their current form the ecological sustainability principles in the FSSD state that:

In a sustainable society, nature is not subject to systematically increasing...

1. ...concentrations of substances extracted from the Earth's crust

(e.g. $\mathrm{CO} 2$ from fossil fuels, or heavy metals and radioactive isotopes),

2. ...concentrations of substances produced by society

(e.g. CFCs, NOx and endocrine disruptors),

3. ... degradation by physical means

(e.g. deforestation, overfishing and overuse of water tables),

Furthermore, so far a single overarching principle for social sustainability has been used in the FSSD:

In a sustainable society,

4. ...people are not subject to conditions that systematically undermine their capacity to meet their needs

(e.g. from the abuse of political and economic power).

Further, the approach utilizes backcasting for planning (to plan with the end in mind and select actions in that context) as well Strategic Guidelines, which aid prioritization of actions into a step-wise transition towards the goal. It is when the gap to the full 
scope of sustainability is on the table, and an overriding strategy is laid out to bridge the gap, that rational choices and combinations of various methods and tools for, e.g., decision support, monitoring and communications can be made.

The FSSD is designed as a combination of these core tenants and intended as a unifying framework to increase the utility and value of other types of support for sustainable development (rather than competing or intending to replace them.)

The FSSD has now been under continuous development over a 25-year consensus and peer-review process including theoretical explorations (Robèrt 1994, Holmberg and Robèrt 2000, Broman et al. 2000, Robèrt 2000, Robèrt et al. 2002, Ny et al. 2006, Missimer 2013) and testing/refinements between scientists and practitioners from business (Electrolux 1994, Robèrt 1997, Anderson 1998, Nattrass 1999, Broman et al. 2000, Leadbitter 2002, Matsushita 2002, Nattrass and Altomare 2002) and policy/government (Gordon 2003, Cook 2004, James and Lahti 2004, Strauss-Kahn 2004). The framework has also been applied to relate various tools, methods and concepts for sustainable development to sustainability and to each other (Robèrt 2000, Robèrt et al. 2002, Robèrt et al. 2010, Robèrt et al. 2013), including eco-design tools (Byggeth and Hochschorner 2006) and for company decision systems (Hallstedt et al. 2010), and has been taught and used to structure teaching, research and cooperation within and between academic institutions (Broman et al. 2002, Waldron et al. 2004, Waldron 2005, Robèrt et al. 2010, Missimer and Connell 2012).

For an updated review of the FSSD with applications, and for references, see Broman and Robèrt (this issue).

\subsection{Social Sustainability within the FSSD}

Though experiences in practice has shown that the FSSD serves well for systematic redesign to support societal compliance with the three principles for ecological sustainability, it has also shown that the FSSD suffers from an under-development of the social dimension (Missimer et al. 2010, Missimer 2013). It is not operational enough to serve analyses, planning, innovation and monitoring of transitions towards social sustainability. The social sustainability principle above is not specific enough about the overriding mechanisms by which peoples' capacity to meet their needs can be eroded, nor is it based on the same thorough systems research approach as the ecological principles are.

Reviews of the general social sustainability literature have also shown the need for further development of the social dimension of sustainability (Missimer 2013) and that social sustainability is often considered the least developed dimension of sustainability (Littig and Griessler 2005, Kunz 2006 Cuthill 2010, Dempsey et al. 2011). As Colontanio et al. $(2009,16)$, at the end of their review, assess:

"The concept of social sustainability has been under-theorised or often oversimplified in existing theoretical constructs [...]. Furthermore, no consensus seems to exist on what criteria and perspectives should be adopted in defining social sustainability. Each author or policy maker derives their own definition according to 
discipline-specific criteria or study perspective, making a generalised definition difficult to achieve."

This suggests that a further development of the social dimension of the FSSD is appropriate and urgently needed. To improve the FSSD by a more operative definition of social sustainability would not only serve planning and transition towards social sustainability per se. It would serve planning and transition to ecological sustainability as well. Re-design towards sustainable practices happens in the creative tension field between social and ecological sustainability, and cooperation to safeguard natural systems relies on viable social systems, e.g., in order to be successful in ecosystem conservation various stakeholders groups need to be involved and able to work together (Robért et al., in this issue).

\subsection{Aim of the paper}

The larger research project of which the work presented in this paper is a part of is guided by the question: how can the FSSD be further developed as regards the social dimension to better aid more concrete planning and decision-making for sustainable development?

The aim of this paper (part one of a two-part series) is to establish a systems-based approach to the social system and identify essential aspects of this system from a sustainability point of view as a basis for developing principles for social sustainability. That is, over and above sustaining essential aspects of the ecological system; what are the essential aspects of the social system that need to be sustained (cannot be systematically degraded) in order to not systematically undermine the capacity of people to meet their needs, now and in the future?

The aim of the second paper is to identify the overriding mechanisms by which these essential aspects of the social system can be degraded and to present a zero-hypothesis for a principled definition of social sustainability.

\section{Methods}

Following the idea of sustainability as a design science (Miller 2011), the overall research project used a design research methodology (e.g., Vaishnavi and Kuechler 2004, Peffers et al. 2007, Blessing and Chakrabarti 2009) to structure its research design. Design research and a design research methodology usually include structured ways of studying of a problem and its context, the suggestion of a solution prototype to the problem, and a testing and rigorous evaluation of the solution prototype in the context. After having studied how social sustainability has been dealt within the FSSD (Missimer et al. 2010), these two tandem papers contribute to the solution prototype of a new approach to social sustainability within the FSSD and therefore are mainly characterized by theory building.

One of the main aims of theory building is the creation of a (mental) model or conceptual system of the phenomenon to be understood and/or explained (Hanneman 
1988, Jaccard and Jacoby 2010). In this case the research focuses on a framework theory (Porter 1991), which is "useful to create a perspective and a viewpoint from which the system can be described" (Törnberg 2011, 12). This also matches well with the choice of a complex (adaptive) systems approach as it is also considered more of a conceptual framework than a traditional theory (Castellani and Hafferty 2010).

The core method in the theory-building phase was conceptual modelling, i.e., modelling of concepts found in literature using the FSSD as a lens. More specifically, this means that the researcher(s) engaged in extensive literature reviews, distilled key concepts from this literature and then used the five levels of the FSSD (described more below) to understand the relationships of these key concepts from a strategic sustainable development perspective.

\subsection{Literature Review}

The review began with looking for systems-based approaches within the social sustainability field. Keywords for the search included "social sustainability" or "social sustainable development" in combination with "systematic review", "system(s) thinking", "system(s) theory", "system(s) dynamics", "holistic", "system", "systematic" or "framework", using various search engines; Libris, worldcat, the Biritish Library catalogue, the Library of congress catalogue as well as google books, ebrary and dawsonera for books; Scopus, EBSCO, Sage Journals online and ISI for journals. This review yielded an interesting overview of social sustainability, but did not result in any leads regarding a systematic, science-based approach to systematically approaching social sustainability and operationalizing it.

Therefore, the literature review moved on to examining the field of sociology regarding systems-based approaches. This was mostly achieved by reviewing textbooks on the various schools within sociology (e.g. Gordon 1991, Allan 2006, Macionis and Plummer 2013) and following up on specific schools that seemed most appropriate, e.g., Parsons or Luhmann due to their focus on systems approaches. At the same time the researcher engaged in studying the history and development of systems thinking and systems approaches, especially in relation to the social system (e.g. Clark et al. 1995, Capra 1996, Ragsdell and Wilby 2001, Johnson 2002, Jackson 2003, Sawyer 2005, Stacey 2007, Meadows and Wright 2008, Castellani and Hafferty 2010, Miller and Page 2009, Mitchell 2009, Ramage and Shipp 2009, Byrne and Callaghan 2013, Capra and Luisi 2014, Holland 2014). The reviewing of this literature lead to the decision to approach the overall research with a complex adaptive systems lens.

Following this decision a search for the keywords "complex adaptive systems" and "social sustainability", lead to the school of thinkers around Folke, Carpenter, Gunderson, Holling, Walker and Berkes (see Folke et al. 2002 for an entry point into the work of this group). Snowballing was then used as a technique to gather the most important and cited articles in relation to complex adaptive systems, complex adaptive management, resilience and adaptive capacity.

This literature was analyzed and key concepts regarding the adaptive capacity of social systems were identified. This focus on adaptive capacity will be further motivated in the Results section. The results of this synthesis are presented in Paper 1. As the aim was to derive mechanisms of destruction, the literature review then moved on to understanding how one might undermine the essential aspects, the details of which will be laid out in paper 2. 


\subsection{Conceptual Modelling}

Following a first phase of literature review described above, conceptual modelling was employed to place the identified concepts in relation to each other and the FSSD lens. Conceptual Modelling is considered a common, but very little understood step in the creation of a model or theory (Robinson 2006, Brooks 2007). Kotiadis and Robinson (2008) describe it as two step process of knowledge acquisition and abstraction that leads to a concept model, which can then be tested or, in cases of computer simulation, translated into a computer model and then tested. However, it is acknowledged that the creation of a conceptual model is often more of an art than a science, as a considerable amount of creative thinking and out-of-the-box thinking is required (Robinson 2006, Brooks 2007, Jaccard and Jacoby 2010).

The conceptual modelling took place in workshops, mostly with the main researchers (for more details see paper 2). The aim for the workshops, which happened in iterative fashion, was to use the key terms gathered from the literature, deduct their semantic meaning and then to use logic to place them at the correct level of the FSSD.

One of the key insights in the FSSD approach is to distinguish a planning endeavor along the lines of 5 levels - the systems level, the success level, the strategic guidelines level, the actions and the tools level. This then allows the systems perspective on planning to evolve from a dynamic and iterative dialogue between two levels of the FSSD - the system level, which describes the system of study, and the success level, which describes the goal or purpose in the system. As noted earlier, a systems perspective is essential so as to not sub-optimize solution approaches and so as to not create solutions that might cause negative impacts somewhere else or for other people. In addition, a focus on defining success allows one to focus on knowing enough about the system to achieve success, rather than getting lost in the overwhelming amount of information about the system itself. What aspects of the system (level 1) are essential to reach success (level 2)? Once the objective is clearly defined, it is possible to look for strategic guidelines (level 3) by which actions (level 4) can be organized in a step-wise strategic plan, and relevant concepts, methods and tools for decision-making and monitoring of the planned transition route can be chosen or developed (level 5). It is this iterative 'ping-pong' between levels that was the base of the conceptual modelling.

The results presented in the tandem papers are simply the final version of the principled definition and the essential aspects at the systems level that they were derived from. Many other aspects are, of course, present at the systems level, but were not identified as essential for social sustainability. The iterative process of the research is hard to represent in the linear fashion of a paper and within the space constraints for most journals. Still, Paper 1 describes the system aspects that have been identified as essential, while Paper 2 lays out the sustainability principles that were derived therefrom in conceptual modelling sessions and through initial testing performed over several years. Only together, however, do they create a full picture of the approach.

The details of the methodology for the entire research project, which these papers are a part of, can be found in Missimer 2015.

\section{Results}


The results section starts off with a description of the approach to social sustainability chosen here and the evidence that was found in the literature for the appropriateness of studying the topic with a systems approach. The main body then presents the aspects of the social system that emerged as essential from the above-mentioned iterative dialogue between the first and second levels of the FSSD.

\subsection{Sustainability in the FSSD}

The Brundtland definition (World Commission on Environment and Development, 1987) speaks to the idea of meeting human needs, now and in the future. How is this different than social sustainability?

On a very fundamental level all human beings have needs that they aim to satisfy. Human needs describe in-born requirements that need to be satisfied in order for the individual to remain healthy - physically, emotionally and mentally. Various categorizations of human needs exist (Burton 1990, Doyal and Gough 1991, Ramsay 1992), many of which overlap substantially (Chittenden 2000, Alkire 2002). Maslow's hierarchy (1943) is probably the most well-known; Max-Neef et al.'s (1991) is a common contemporary one used in the (economic and sustainable) development conversation. Most human beings have the desire and some innate capacity to satisfy their own needs by themselves, and use this capacity if they are not hindered to do so by the parts of the social system on which they depend - other people, organization or larger societal structures (e.g. the economic system). At the same time, it is obvious that many of the needs, such as participation, affection and others can only be satisfied in community with others. So, by design, humans are a social species. Malinowski (1944), e.g. argues that the creation for opportunities to meet needs is one of the main reason for the development of society (see also Maturana and Varela 1980). So individual humans are capable of meeting their own needs, but are dependent on the ecological and the social systems to do so.

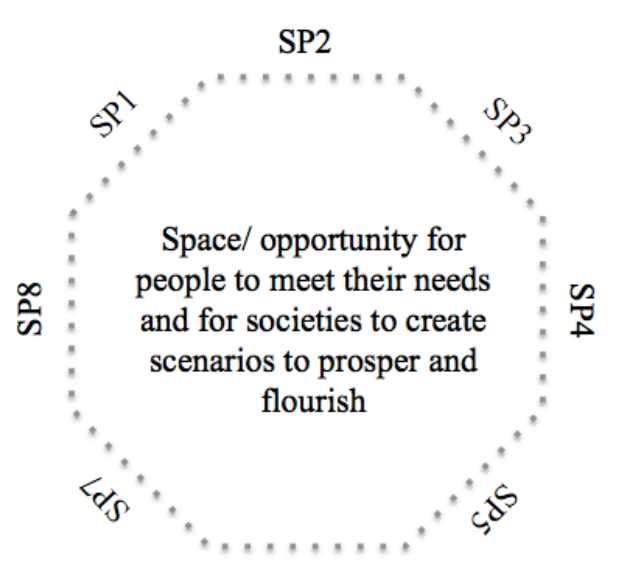

9dS

Figure 2: Sustainability principles as boundary conditions
The FSSD therefore approaches social sustainability from this social system's perspective. Sustainability is about the elimination of basic mechanisms of systematic degradation of essential aspects of both the ecological and the social system. Such basic mechanisms can then act as exclusion criteria for re-design, thereby serving as boundary conditions within which the system can continue to function and evolve, outside of which it cannot.

In that sense, the definition of sustainability is not about a flourishing of human life or all needs being met, but about the basic conditions that are necessary for the ecological and social systems to not systematically degrade. By clustering a 
myriad of downstream impacts into overriding mechanisms of degradation and equipping them with a "not" to serve as exclusion criteria, boundary conditions for redesign are derived. The sustainability of these two systems and the definition of the goal (sustainability) at the principle level then creates the space and opportunity for people to meet their needs in whatever way they chose and for societies to create scenarios to prosper and flourish (Figure 2 serves as visualization for this concept of boundary conditions). A socially robust system may be most needed at times of very harsh conditions such as natural catastrophes or economic crises. The boundary conditions for a sustainable system allow for various value systems and political ideas that are essential for creative community building. They also allow for a diversity of innovation, e.g., on how societies design systems to increase their capacity to respond to changes through adaptations and transformations (Westley et al. 2012). In this way, the boundary conditions are really unifying, allowing for creative community building across such polarities that are based on true differences in values, not on poor knowledge about the basic constituents of the system, or on misunderstandings of each other (Broman and Robért, in this issue). The scientific approach of this study is designed to get as close as possible to such a definition of social sustainability, and to scrutinize it and refine it in action research in organizations.

\subsection{The Social System as a Complex Adaptive System}

The FSSD is based on a systems approach. However, in the social sciences, a systems approach has long been contentious. Even though social systems theory was a dominant strand in traditional sociology (Castellani and Hafferty 2010), this kind of thinking about large-scale processes was later largely abandoned or at least marginalized (Walby 2003, 2007). However, recently systems thinking or rather, complexity theory, has gained increased popularity in the social sciences (Törnberg 2011, Nowotny 2005). Some authors even go as far as saying that an overhaul of sociological theory and method is needed and that complexity science is the most promising new approach (Byrne 1998, Castellani and Hafferty 2010, Urry 2003).

More concretely, Walby $(2003,2007)$ argues that complexity theory overcomes the challenges levied at earlier systems thinking approaches, namely that it lets go of a focus on equilibrium and functionalist approaches to system-parts interactions and instead emphasizes dynamic process and co-evaluation of systems. She further states that complexity theory offers new ways of thinking about some of the classic dilemmas in social science:

- "The tension between the search for general theory and the desire for contextual and specific understandings $(2003,1)$ "

- "Combining an understanding of both individual and social structure, that does not deny the significance of the self-reflexivity of the human subject while yet theorising changes in the social totality $(2003,2)$ "

Like all living systems, human social systems can be considered not only complex, but complex adaptive systems (e.g., Clayton and Radcliffe 1996). Complex systems are systems that are dynamic networks of relationships rather than an aggregation of the individual static entities; complex adaptive systems are systems where the individual and collective behavior also mutates. Castellani and Hafferty $(2010,7)$ argue that in human social systems the 'things' are human social agents (individuals and various 
constellations of groups) and the various relationships between these social agents make up the interactions in the system. This then includes specific sub-systems of the lager social system such as communities, nations, institutions or companies and direct interactions as well as more indirect, intangible ones such as cultural systems. ${ }^{1}$

Clark et al. $(1995,36)$ clarify that "as systems evolve they usually do so in the direction of increasing complexity. By this we mean not only that the number of the participating components of the system increases but also that the pattern of interrelationships amongst these components is also becoming more elaborate - that is their number and type is increasing”. In the social system this evolution is clearly evident, amplified by the many diverse and free-willed agents it is made up of. ${ }^{2}$

\subsection{Essential Aspects of Complex Adaptive Social Systems}

The research field of resilience theory and complex and adaptive management has emerged to study and understand the dynamics of working with complex adaptive systems (Berkes et al. 2003, Folke et al. 2005, Nelson et al. 2007). Although focused on socio-ecological systems, i.e., the interaction between social and ecological systems, it provides many insights for the social system itself and comes up in the literature as the main field connecting social sustainability and complex adaptive systems.

Complex adaptive systems are inevitably characterized by uncertainty, change and surprise, which in return requires flexibility and adaptation in dealing with the system. Resilience was originally defined as the capacity of a system to absorb disturbance and re-organize while undergoing change so as to still retain essentially the same function, structure, identity and feedbacks (Walker et al. 2004). ${ }^{3}$ It focused on the ability to absorb and shape change as well as the ability for renewal (Berkes et al. 2003, Folke et al. 2005, Folke 2006, Nelson et al. 2007). Folke (2006) has since argued to move away from the focus on maintaining functions to also include adaptability and sometimes even transformability (Folke et al., 2010) in the definition of resilience. The latter stems from the idea that transformational change at smaller scales may enable adaptations and hence resilience at larger scales (ibid). Adger (2000) simply defines social resilience as the ability of human communities to withstand external shocks to their social infrastructure, such as environmental variability or social, economic and political upheaval. ${ }^{4}$

The literature reveals that the key feature that allows complex adaptive systems to continue despite the constant change and uncertainty within them and in their

\footnotetext{
${ }^{1}$ Some (e.g., Stichweh 2000) claim, that at this point, the entire world is connected into one global system.

2 The increasing level of complexity of social life in modern society, partly through globalization and the development and spread of technology, and the difficulty this brings in coordinating our systems is a common topic also in mainstream sociology (Giddens 1990, 1991, Luhmann 1988).

${ }^{3}$ It is important to note that, even though the literature on socio-ecological systems focuses primarily on changes in the ecological system, the 'disturbance' can come from changes in the physical environment or from changes within the social system (Jansen et al. 2007)

${ }^{4}$ While ecological and social systems do not function entirely the same, nor can the study of resilience and adaptability be directly applied from one to the other (Adger 2000), the social system is a living system and it would therefore make sense to keep the above in mind also when thinking about the social system in itself.
} 
environment, is what is called adaptive capacity. The literature further reveals five essential aspects of adaptive capacity:

\subsubsection{Diversity}

Diversity is repeatedly mentioned as an important aspect (Folke et al. 2002, Walker et al. 2006, Norberg and Cumming 2006, Chapin et al. 2010). Folke et al. $(2002,19)$ claim "diversity is not just insurance against uncertainty and surprise. It also provides a mix of components whose history and accumulated experience help cope with change, and facilitates redevelopment and innovation following disturbance and crisis". In essence, more diversity leads to more variety and in an environment of constant change and uncertainty, one does not always know what will be needed in the future; therefore, having as many options as possible is the best strategy to be resilient in the long run. Diversity is also specifically mentioned in relation to types of knowledge and as including, e.g., indigenous knowledge in understanding a system (Folke et al. 2002, 2005). In addition, an increasing body of research focuses specifically on diversity in governance as a source for resilience (Burger et al. 2001, Ostrom et al. 2002, Berkes et al. 2003, Dietz et al. 2003, Folke et al. 2005, Ostrom 2005).

\subsubsection{Learning}

Many authors stress the need for flexibility and learning to deal with the complexity and constant changes (Gunderson 2001, Scheffer et al. 2001, Folke et al. 2002, 2004, Olsson et al. 2004, Walker et al. 2006, Nelson et al. 2007, Chapin et al. 2010). Learning in this sense means to be able to sense changes and respond to them effectively. The literature focuses specifically on social and institutional learning and includes social memory, the capacity to learn from experience, as a mechanism (McIntosh 2000, Folke et al. 2005). Scheffer et al. (2001) discuss how resilient systems must not become rigid and monolithic in any way, but instead constantly learn and adapt to the situation. Folke et al. (2002, 47) claim that "flexible social networks and organizations that proceed through learning-by-doing are better adapted for long-term survival than are rigid social systems (that have set prescriptions [...])". The importance of the aspect of learning is also supported by literature in the field of organizational learning (e.g., Senge 1990).

\subsubsection{Self-organization}

Complex adaptive systems are usually self-organized systems without system-level intent or centralized control (Clark et al. 1995, Levin 1998, Westley 2002, Walker et al. 2006). Walker et al. (2004) explain that, although the system is "dominated by individual human actors who do exhibit intent, the system as a whole does not (as in the case of a market)". It is this capacity for self-organization that is especially important when confronted with a sudden change in the environment (Olsson et al. 2004, Folke et al. 2005, Norberg and Cumming 2006, Folke 2006, Osbahr et al. 2010). Folke et al. (2002) emphasize the importance of creating opportunity for self-organization towards socio-ecological sustainability.

\subsubsection{Trust (Social Capital)}


Another aspect mentioned is that of social capital as a necessity to coordinate the system in its adaptation and allow for collective action (Pretty and Ward 2001, Ostrom and Ahn 2003, Pretty 2003, Adger 2003, Folke et al. 2003, Olsson et al. 2004, Folke et al. 2005, Walker et al. 2006, Osbahr et al. 2010). Folke et al. (2005) specifically claim that social capital increases the flexibility of management of organizations and institutions.

The concept of social capital is a confusing and often-criticized one (e.g., Arrow 2000); therefore some caution and great analytical precision is required. Rothstein (2005) makes a convincing argument that social capital is a function of networks and trust, so the quantity of connections multiplied by the quality of the connections. He further goes on to argue that trust is the main variable in social capital and that many others that are discussed are not valid in the same way. Others in the field agree that trust is one of the main variables that creates value in social systems (Putnam 2000, Fukuyama 2002, Wollebaek and Selle 2008). Trust is also discussed as a key element of social life in other social sciences - it is often termed the fabric, which binds society together (Hollis 1998, Luhmann 2000, Potter 2002, Caldwell and Clapham 2003). Erosion of trust, on the other hand, can lead to a negative and self-re-enforcing spiral causing a dysfunctional social system, the "social entrapment", and it calls for very large efforts of leadership and powerful policy-making to open the trap up again (Rothstein 2005, 2007).

Trust also plays a special role in relation to complex adaptive systems. In these systems it is impossible for one or a few individuals to understand or completely control the entire system; therefore, with more and more complexity, one must rely more and more on others to make decisions and choose viable alternatives (Meijboom et al. 2006, Meijboom 2008). A way to deal with the risk and uncertainty inherent in this complexity is by trusting (Lahno 2001, Meijboom et al. 2006). Friedman (2007, 557-558), e.g., states "without trust, there is no open society, because there are not enough police to patrol every opening... without trust there can also be no flat world, because it is trust that allows us to take down walls, remove barriers, and eliminate friction at borders". Trust is therefore seen as a quality of connection, which allows the system to remain together despite the level of internal complexity. In return, as discussed above, it allows for collective adaptation to the constant change produced by the complex adaptive systems around us (rather than only individual, competing adaptive strategies).

In the organizational studies field, some have argued that there is even tangible economic benefit from trust, because trust facilitates exchanges among individuals and enhances cooperation and lowers transaction costs (Coleman 1990, Putnam 1993, Fukuyama, 1995, 2002).

\subsubsection{Common meaning (Social Capital)}

A final important aspect in terms of adaptive capacity for social systems is common meaning. In relation to social capital in complex adaptive social systems, Scheffer et al. (2001, 229) state that "It is important not to neglect, however, the role of common culture and meaning in the creation of social capital, both horizontal and vertical. Particularly in the absence of a long history of reciprocity and the trust that engenders, stakeholders will often make the decision to enter into the initial reciprocities on the 
basis of their belief that they share representations, interpretations, and systems of meaning with the other party or parties (Nahapiet and Ghoshal 1998)."

Humans are a meaning-making and meaning-seeking species (e.g., Cacioppo et al 2005, Marsen 2008, Park 2011; for a review of the literature on meaning see Park 2010). In fact, this seems to be hard-wired into our brains (Baumeister and Vohs 2005). Klinger (1998, 33) states, "the human brain cannot sustain purposeless living. It was not designed for that. Its systems are designed for purposive actions, and when blocked, they deteriorate, and the emotional feedback from idling those systems signals extreme discomfort and motivates the search for renewed purpose and hence meaning." This idea that humans are constantly looking for meaning and purpose is a concept in several disciplines, such as sociology, anthropology, and other social sciences (Kurzman 2008). ${ }^{5}$ Giddens (1984), e.g., speaks of structures of signification, the interpretations or meanings that individuals use to make sense of their experience, as an important element of the social system. Frankl (e.g., 1962, 1986), based on his experience in a concentration camp, made meaning famous in his psychological theory and practice of logotherapy.

Common meaning as an important concept is also supported by studies in management, where it has been well documented that, in order to exist and strive, social systems (in this case companies) need a clear purpose (e.g., Collins and Porras 2002). Already Ackoff and Emery (2005) in earlier attempts to look at social systems from a systems perspective, asserted that social systems are indeed purposeful systems.

In summary, five aspects of the social system that are essential from a social sustainability point of view have been identified. It is important to emphasize again that the aspects presented here are the final result of an iterative process with many loops. In paper 2 we will explore by what overriding mechanisms these essential aspects can be degraded and only together do they provide a full picture of a new approach to social sustainability within the FSSD.

\section{Discussion}

Shrivastava et al. (2013) as well as Lang et al. (2012), among others, argue that sustainability-science is a transdisciplinary science. While no clear consensus on the term transdisciplinary exists (e.g., Wickson et al. 2006, Pohl and Hadorn 2007), the general approach includes seeing the work as real-life phenomena-driven (not theorydriven) and based on collaboration between different academic disciplines, and also between academic and non-academic actors; all with the aim of integrative synthesis. It is also "co-evolutionary in the sense that research and application occur iteratively, modifying each other" (Shrivastava et al. 2013, 236). It is indeed this integrative synthesis that this research also aims for. The FSSD is a transdisciplinary framework (both in that it is not based in a particular discipline, but also that it is co-developed by academics and practitioners), which was utilized here as the lens and supplemented with an understanding of the dynamics of the social system from various disciplinary angles.

\footnotetext{
${ }^{5}$ The idea is also the basis of the constructivism theory in pedagogy (e.g., Bellin 2009) and the psychology of development and learning in children (e.g., Kagan 1981, Wells 2009).
} 
This integrative synthesis also makes sense because (social) life does not occur in disciplines. The most comprehensive understanding therefore comes from combining different approaches and seeing multiple perspectives at the same time.

Metzner (2000) argues that the social sciences have concerned themselves with a wide variety of social objectives, strategies and measurement instruments, but often with little consideration of the sustainability perspective. This and their observation that the social sustainability discourse is often based on current political agendas and conversations (Omann and Spangenberg 2002) leads Spangenberg und Omann to reason that: "This deficit makes it difficult to systematise the different elements responding to certain problems or project priorities, which dominate the current debate, and this in turn is a major obstacle for any attempt to prioritise among the criteria developed in an ad hoc fashion, for strategy development and assessment" (2006, 320).

The transdisciplinary and systems approaches, and specifically the FSSD, however, are not a substitute for the understanding that the social sciences provide us of the social system. The many approaches e.g., on needs (e.g Max-Neef et al. 1991, Maslow 1943); freedoms (Sen and Nussbaum 1993, Sen 1999), on well-being (e.g., McGillivray, 2007) on income and wealth equality (e.g. Sen 1992, Wilkinson and Pickett 2009, Piketty 2014), are all valuable pieces of understanding in the larger social dynamics. The approach presented here merely helps to frame this more specific knowledge and give an understanding of how to utilize it in the context of strategic sustainable development. The two approaches complement each other and only together become a more powerful resource in our move towards sustainability.

Another challenge is often levied against this kind of approach towards sustainability. Many argue that sustainability is a 'wicked' problem - a problem that is complex, where uncertainty is high, where there is debate over values and where solutions are not obvious (Rittel and Webber 1973, Funtowicz and Ravetz 1993) and that therefore a systems approach which includes participatory elements and deliberations about values (e.g. soft systems approaches) is more appropriate. Similarly to the above, we argue, that these two approaches are compatible and strengthen each other. This will be returned to this in paper 2 .

\subsection{Validity}

The approach presented in this paper has led to the identification of five aspects of a social system that are essential to sustain (cannot be systematically degraded) from a sustainability point of view: trust, common meaning, diversity, capacity for learning and capacity for self-organization. This is the basis for the elaboration of social sustainability principles presented in Paper 2.

From a methodological perspective, the research to this point has mostly focused on conceptual modeling and as such employed literature reviews, semantics and logic. While parts of the theory have been supported in other research fields such as the field of complex adaptive management, the combination of the different parts has not. Thus, there are numerous ways in which it might be wrong. However, the aim was never an explanatory theory, but rather a framework theory that can guide thinking about concrete planning and action towards sustainability based on the best available science. The trans-disciplinary research approach and the many theories and findings in different 
fields that point to similar results also add to the validity. Paper 2 will discuss further validity challenges in design research, which this research project is methodologically situated in.

Overall, the limitations in determining validity act as an encouragement to be as objective, accurate, clean and transparent as possible, so that others may find holes in the logic and update the theory. As Gordon $(1991,110)$ points out "a good model can be expanded to include additional factors when their relevance is suspected". Therefore, the model of social sustainability proposed here is a starting point, expandable and condensable if necessary.

\section{Conclusion}

This paper is part of a larger project of exploring how the social dimension of the Framework for Strategic Sustainable Development could be further developed. Researchers and practitioners in the sustainability field have requested this further development for quite some time. The aim of this paper was to establish a systems-based approach to the social system and identify essential aspects of this system from a sustainability point of view as a basis for developing principles for social sustainability. Such a systems-based and scientific approach to (social) sustainability is important because it helps overcome differences based solely on opinion and sub-optimization in the solution space, which is prevalent in much of the current discussion on social sustainability. Trust, Common Meaning, Diversity, Capacity for Learning and Capacity for Self-organization were identified as essential aspects of the social system and paper 2 will take these as a starting point to derive operational social sustainability principles that can be used in any context to help move society towards sustainability.

\section{Acknowledgements}

Financial support was provided by the FUTURA foundation and is hereby gratefully acknowledged. FUTURA was not involved in the study design, the collection, analysis and interpretation of data, in the writing of the report or in the decision to submit the article for publication.

\section{References}

Ackoff, R. L., \& Emery, F. E. 2005. On purposeful systems: An interdisciplinary analysis of individual and social behavior as a system of purposeful events. New Brunswick, NJ, USA: Transaction Publishers.

Adger, W. N. 2000. Social and ecological resilience: are they related? Progress in Human Geography. 24(3), pp.347-364.

Adger, W.N. 2003. Social capital, collective action and adaptation to climate change. Economic Geography. 79, p.387-404.

Alkire, S. 2002. Dimensions of human development. World Development. 30(2), pp. 181-205.

Allan, K.D. 2006. Contemporary Social and Sociological Theory: Visualizing Social Worlds (Ed. 1). Sage Publisher

Amini, M. \& Bienstock, C.C. 2014. Corporate sustainability: an integrative definition and framework to evaluate corporate practice and guide academic research. Journal of Cleaner Production 76: 12-19. 
Anderson, R. C. 1998. Mid course correction - toward a sustainable enterprise: The Interface model. Atlanta, USA: The Peregrinzilla Press.

Arrow, K. 2000. Observations on social capital. In Social capital: A multi-faceted perspective, Dasgupta, P. \& Serageldin, I., eds. Washington, D.C.: World Bank. Pp. 3-5.

Baumeister, R. F. \& Vohs, K.D. 2005. The Pursuit of Meaningfulness in Life. In Handbook of Positive Psychology. Snyder, C. R. \& Lopez, S. J. (Eds.). Cary, NC, USA: Oxford University Press. p 608-619

Bellin, Z. J. 2009. Exploring a Holistic Content Approach to Personal Meaning. Doctoral Thesis. Loyola University in Maryland. Available at http://www.meaningthroughbeing.com/wpcontent/uploads/2010/03/Bellin-Dissertation-PDF.pdf

Ben-Eli, M. 2012. The cybernetics of sustainability: Definition and underlying principles." Enough for All forever: A Handbook for Learning about Sustainability, Murray J, Cawthorne G, Dey C and Andrew C (eds.). Champaign, IL, Common Ground Publishing: University of Illinois. Available at:

http://www.sustainabilitylabs.org/files/The_Cybernetics_of_Sustainability\%20FF.pdf

Berkes, F., Colding, J., \& Folke, C., eds. 2003. Navigating Social-Ecological Systems: Building Resilience for Complexity and Change. Cambridge, UK: Cambridge Univ. Press.

Blessing, L. \& Chakrabarti, A. 2009. DRM, a Design Research Methodology. London: Springer Verlag.

Broman, G., Byggeth, S. \& Robèrt, K-H. 2002. Integrating environmental aspects in engineering education. International Journal of Engineering Education. 18(6), pp. 717-724.

Broman, G., Holmberg, J. \& Robèrt, K.-H. 2000. Simplicity Without Reduction: Thinking Upstream Towards the Sustainable Society. Interfaces. 30(3), pp.13-25.

Broman, G., Robèrt K.-H., 2015. A framework for strategic sustainable development (in this issue).

Brooks, R. J. 2007. Conceptual modelling: framework, principles, and future research. Working Paper 2007/011. Lancaster University Management School.

http://eprints.lancs.ac.uk/48885/1/Document.pdf

Burger, J., Ostrom, E., Norgaard, R.B., Policansky, D. \& Goldstein, B.D. 2001. Protecting the Commons. A Framework for Resource Management in the Americas. Washington, DC: Island Press

Burton, J. W., ed. 1990. Conflict: Human needs theory. New York: St. Martin's Press.

Byggeth, S. \& Hochschorner, E. 2006. Handling Trade-offs in Ecodesign Tools for Sustainable Product Development and Procurement. Journal of Cleaner Production. 14(15-16), pp.14201431.

Byrne, D. \& Callaghan, G. 2013. Complexity theory and the social sciences: The state of the art. Routledge.

Byrne, D. 1998. Complexity Theory and the Social Sciences. London, UK: Routledge

Cacioppo, J.T., Hawkley, L.C., Rickett, E. M. \& Masi, C.M. 2005. Sociality, Spirituality, and Meaning Making: Chicago Health, Aging, and Social Relations Study. Review of General Psychology. 9(2), pp. 143-155.

Caldwell, C. \& Clapham, S.E. 2003. Organizational Trustworthiness: An International Perspective. Journal of Business Ethics 47, pp.349-364.

Capra, F. \& Luisi, P.L. 20014. The systems view of life: a unifying vision. Cambridge, UK: Cambridge University Press. 
Capra, F. 1996. The web of life: A new scientific understanding of living systems. Anchor Castellani, B \& Hafferty, F. W. 2010. Sociology and Complexity Science: A New Field of Inquiry. Berlin/Heidelberg, Germany: Springer

Chapin F. S., Carpenter, S. R., Kofinas, G.P., Folke, C., Abel, N., Clark, W.C., Olsson, P., Smith, D. M. S., Walker, B., Young, O.R., Berkes, F., Biggs, R., Grove, J.M., Naylor, R. L., Pinkerton, E., Steffen, W. \& Swanson, F.J. 2010. Ecosystem stewardship: sustainability strategies for a rapidly changing planet. Trends in Ecology and Evolution. 25(4), pp. 241- 249

Chasin, F. 2014. Sustainability: Are We All Talking About the Same Thing? Proceedings of the ICT for Sustainability, 342-351.

Chittenden, D. 2000. System and Human Needs: Comparative Analysis of a Systems Framework for Finding Indicators for Sustainable Development with a Theory of Fundamental Human Need : a Thesis Submitted in Partial Fulfillment of the Requirements for the Degree of Master of Chemical and Process Engineering at the University of Canterbury, Christchurch, New Zealand.

Clark, N., Perez-Trejo, F. \& Allen, P.M. 1995. Evolutionary Dynamics and Sustainable Development: A systems Approach. Cheltenham, UK: Edward Elgar Publishing Ltd.,

Clayton, A. \& Radcliffe, N.J. 1996. Sustainability: a systems approach. London: Earthscan/James \& James.

Colantonio, A., Dixon, T., Ganser, R., Carpenter, J. \& Ngombe, A. 2009. Measuring Socially Sustainable Urban Regeneration in Europe. Oxford Institute for Sustainable Development (OISD), School of the Built Environment, Oxford Brookes University

Coleman, J.S. 1990. Foundations of Social Theory, Cambridge: Belknap Press

Collins, J.C. \& Porras, J.I. 2002. Built to last. ( $3^{\text {rd }}$ ed). New York: Harper Collins Publisher Inc.

Cook, D. 2004. The natural step towards a sustainable society. Green Books Ltd, Dartington, UK.

Cuthill, M. 2010. Strengthening the 'Social' in Sustainable Development: Developing a Conceptual Framework for Social Sustainability in a Rapid Urban Growth Region in Australia. Sustainable Development. 18(6), pp.362-373.

Dempsey, N., Bramley, G., Power, S. \& Brown, C. 2011. The social dimension of sustainable development: Defining urban social sustainability. Sustainable Development. 19(5), pp.289-300.

Dietz, T., Ostrom, E. \& Stern, P.C. 2003. The struggle to govern the commons. Science. 302, pp.1907-1911.

Doyal, L. \& Gough, I. 1991 A theory of human need. New York: Palgrave Macmillan

Electrolux. 1994. Electrolux Annual Report. Electrolux, Stockholm, Sweden.

Folke, C. 2006. Resilience: The emergence of a perspective for social-ecological systems analyses. Global Environmental Change. 16, pp.253-267

Folke, C., Carpenter, S., Elmqvist, T., Gunderson, L., Holling, C. S., Walker, B., Bengtsson, J., Berkes, F., Colding, J., Danell, K., Falkenmark, M., Gordon, L., Kasperson, R., Kautsky, N., Kinzig, A., Levin, S., Mäler, K. G., Moberg, F., Olsson, P., Oström, E., Reid, W., Rockström, J., Savenije, H. \& Svedin, U. 2002. Resilience and Sustainable Development: Building Adaptive Capacity in a World of Transformations-Scientific Background Paper on Resilience for the process of The World Summit on Sustainable Development on behalf of The Environmental Advisory Council to the Swedish Government. Stockholm: Ministry of the Environment.

Folke, C., Carpenter, S., Walker, B., Scheffer, M., Elmqvist, T., Gunderson, L., \& Holling, C. S. 2004. Regime shifts, resilience, and biodiversity in ecosystem management. Annual Review of Ecology, Evolution, and Systematics. (35), pp.557-581. 
Folke, C., Colding, J. \& Berkes, F. 2003. Synthesis: building resilience and adaptive capacity in social-ecological systems. In Navigating Social-Ecological Systems: Building Resilience for Complexity and Change. Berkes, F., Colding, J. \& Folke, C. (eds). Cambrdige, UK: Cambridge University Press, pp. 352-87

Folke, C., Hahn, T., Olsson, P. \& Norberg J. 2005. Adaptive governance of social-ecological systems. Annual Review of Environment and Resources. 30, pp.441-473.

Frankl, V.E. 1962. Man's search for meaning: An introduction to logotherapy. New York: Simon and Schuster.

Frankl, V.E. 1986. Logotherapy and the challenge of suffering. Review of Existential Psychology \& Psychiatry. 1, pp. $63-67$.

Friedman, T.L. 2007. The world is flat : a brief history of the twenty-first century. $2 \mathrm{nd}$ rev. and expanded ed. New York : Farrar, Straus and Giroux.

Fukuyama, F. 1995. Trust: The social virtues and the creation of prosperity. New York: Free Press.

Fukuyama, F. 2002. Social Capital and Development: The Coming Agenda. SAIS Review. 20(1), pp. 23-37.

Funtowicz, S. O. \& Ravetz, J.R. 1993. Science for the post-normal age. Futures. 25(7):739-55.

Giddens, A. 1984. The Constitution of Society. Outline of the Theory of Structuration.

Cambridge, UK: Polity Press.

Giddens, A. 1990. The Consequences of Modernity. Cambridge: Polity Press

Giddens, A. 1991. Modernity and Self-Identity: Self and society in the late modern age. Cambridge, UK: Polity Press.

Glavič, P. \& Lukman, R. 2007. Review of sustainability terms and their definitions. Journal of cleaner production 15.18: 1875-1885.

Gordon, S. 1991. The History and Philosophy of Social Science. London and New York: Routledge.

Gordon, S. 2003. The Natural Step and Whistler's journey towards sustainability. Paper presented at the Sustainable Mountain Communities Conference in Banff, Alberta.

Gunderson, L. H. 2001. South Florida: the reality of change and the prospects for sustainability: managing surprising ecosystems in Southern Florida. Ecological Economics. 37(3), pp.371-378.

Hallstedt, S., Ny, H., Robèrt, K.-H. \& Broman, G. 2010. An Approach to Assessing Sustainability Integration in Strategic Decision Systems for Product Development. Journal of Cleaner Production. 18(8), pp.703-712

Hanneman, R. 1988. Computer-assisted theory building. Thousand Oakes, CA, US: Sage Publications

Holland, J. H. 2014. Complexity: A very short introduction. Oxford, UK: Oxford University Press.

Hollis, M. 1998. Trust within Reason. Cambridge: Cambridge University Press

Holmberg, J. \& Robèrt, K-H. 2000. Backcasting from non-overlapping sustainability principles - a framework for strategic planning. International Journal of Sustainable Development and World Ecology. 7, pp.291-308.

Hopwood, B, Mellor, M. \& O'Brien, G. 2005. Sustainable development: mapping different approaches. Sustainable development 13.1: 38-52. 
Huesemann, M. H. 2001. Can pollution problems be effectively solved by environmental science and technology? An analysis of critical limitations. Ecological Economics. 37(2), p.271288.

Hull, Z. 2008. Sustainable development: premises, understanding and prospects. Sustainable Development 16.2: 73-80.

Jaccard, J. \& Jacoby, J. 2010. Theory Construction and Model building skills. New York: Guilford press.

Jackson. M. 2003. Systems Thinking: Creative Holism for Managers. Chichester, West Sussex, England: John Wiley and Sons

Jacobs, M. 1999. Sustainable development: a contested concept. In Fairness and futurity: essays on environmental sustainability and social justice. Dobson, A, ed. Oxford, UK: Oxford University Press.

James S. \& Lahti T. 2004. The Natural Step for communities: how cities and towns can change to sustainable practices. Gabriola Island, British Columbia, Canada: New Society Publishers.

Janssen, M. A., Anderies, J. M., \& Ostrom, E. 2007. Robustness of social-ecological systems to spatial and temporal variability. Society and Natural Resources, 20(4):307-322.

Johnson, S. 2002. Emergence: the connected lives of ants, brains, cities and software. Scribner

Johnston, P., Everard, M., Santillo, D \& Robèrt, K.-H. 2007. Reclaiming the definition of sustainability. Environmental Science and Pollution Research. 14 (1): 60-66.

Kagan, J. 1981. The second year: The emergence of self awareness. Cambridge, MA: Harvard University Press.

Kajikawa, Y., Francisco T. \& Yamaguchi, K. 2014. Sustainability science: the changing landscape of sustainability research. Sustainability science 9.4: 431-438.

Klinger, E. 1998. The search for meaning in evolutionary perspective and its clinical implications. In The Human Quest for Meaning: A Handbook of Psychological Research and Clinical Applications. Wong, P. \& Fry, P. (Eds.). New Jersey: Laurence Erlbaum Associates. pp. $27-50$.

Kotiadis, K. \& Robinson S. Conceptual modelling: knowledge acquisition and model abstraction. Proceedings of the 40th Conference on Winter Simulation. Winter Simulation Conference, 2008.

Kunz J. 2006. Social Sustainability and Community Involvement in Urban Planning. University of Tampere: Tampere, Finland.

Kurzman, C . 2008. Introduction: Meaning-Making in Social Movements. Anthropological Quarterly. 81(1), pp. 5-15.

Lahno, B. 2001. On The Emotional Character Of Trust. Ethical Theory and Moral Practice. 4, pp.171-189.

Lang, D.J., Wiek, A., Bergmann, M., Stauffacher, M., Martens, P., Moll, P., Swilling, M., Thomas, C.J., 2012. Transdisciplinary research in sustainability science: practice, principles, and challenges. Sustain Science 7, pp. 25-43.

Leadbitter, J. 2002. PVC and sustainability. Progress in Polymer Science. 27(10), pp.2197-2226.

Levin, S. A. 1998. Ecosystems and the biosphere as complex adaptive systems. Ecosystems. 1(5), pp.431-436.

Littig, B. \& Griessler, E. 2005. Social sustainability: a catchword between political pragmatism and social theory. International Journal of Sustainable Development. 8(1), pp.65-79. 
Lozano, R. 2008. Envisioning sustainability three-dimensionally. Journal of Cleaner Production 16.17: $1838-1846$.

Luhmann, N. 1988. Familiarity, confidence, trust: problems and alternatives in: Trust: Making and breaking cooperative relations. Gambetta, D. (ed.). Oxford: Basil Blackwell, 94-107

Luhmann, N. 2000. Vertrauen, ein Mechanismus der Reduktion der sozialer Komplexität. 4. Auflage, Stuttgart: Lucius \& Lucius.

Macionis J.J. \& Plummer, K. 2013. Sociology: A global Introduction $\left(5^{\text {th }}\right.$ eds). Pearson Education Limited

Malinowski, B. 1944. A scientific theory of culture. Chapel Hill: University of North Carolina.

Marsen, S. 2008. The Role of Meaning in Human Thinking. Journal of Evolution and Technology . 17(1), pp. 45-58.

Marsden, G. , Kimble, M. , Nellthorp, J. \& Kelly, C. 2010 Sustainability Assessment: The Definition Deficit. International Journal of Sustainable Transportation 4:4, 189-211

Maslow, A.H. 1943. A theory of human motivation. Psychological Review. 50(4), pp.370-96.

Matsushita. 2002. Environmental sustainability report 2002. Matsushita Electric Industrial Co., Ltd. Osaka, Japan.

Maturana, H. R. \& Varela, F. J. 1980. Autopoiesis and Cognition. The Realization of the Living. Dordrecht, Holland: D. Reidel.

Max-Neef, M., Elizalde, A. \& Hopenhayn, M. 1991. Human scale development: conception, application and further reflections. New York: Apex.

McGillivray, M (eds). 2007. Human well-being: Concept and measurement. New York, NY, USA: Palgrave Macmillan

McIntosh, R.J. 2000. Social Memory in Mande. In The Way the wind blows: climate, history and human action. McIntosh, R.J., Tainter, J.A., \& McIntosh, S.K. (eds.). New York: Columbia Univ Press: $141-180$

McKenzie, S. 2004 Social Sustainability: Towards Some Definitions, Hawke Research Institute, Working Paper Series No. 27, University of South Australia.

Meadows, D. H. \& Wright, D. 2008. Thinking in systems: A primer. Chelsea Green Publishing.

Meijboom, F. L. B., Visak, T. \& Brom, F.W.A. 2006. From Trust To Trustworthiness: Why Information Is Not Enough In The Food Sector. Journal of Agricultural and Environmental Ethics. 19, pp.427-442.

Meijboom, F. L.B. 2008. Problems Of Trust: A Question Of Trustworthiness - An ethical inquiry of trust and trustworthiness in the context of the agricultural and food sector. Doctoral Dissertation, Utrecht University

Metzner, A. 2000. Caring capacity and carrying capacity - a social science perspective. Papers Presented at the INES 2000 Conference: Challenges for Science and Engineering in the 21st Century, Stockholm.

Miller, J. H. \& Page, S.E. 2009. Complex adaptive systems: an introduction to computational models of social life: an introduction to computational models of social life. Princeton, NJ, USA: Princeton University Press.

Miller, T. R., 2011. Constructing Sustainability: A Study of Emerging Scientific Research Trajectories. (PhD Thesis). Arizona State University. Available at http://repository.asu.edu/attachments/56608/content/Miller_asu_0010E_10655.pdf (Accessed January 25th, 2013) 
Missimer, M. \& Connell, T. 2012. Pedagogical Approaches and Design Aspects To Enable Leadership for Sustainable Development. Sustainability: The Journal of Record 5(3), pp. 172181.

Missimer, M. 2013. The social dimension of strategic sustainable development. Licentiate Dissertation, Blekinge Institute of Technology.

Missimer, M. 2015. Social Sustainability within the Framework for Strategic Sustainable Development. Doctoral Dissertation, Blekinge Institute of Technology

Missimer, M., Robèrt K - H., Broman G. \& Sverdrup, H. 2010. Exploring the possibility of a systematic and generic approach to social sustainability. Journal of Cleaner Production. 18(1011), pp.1107-1112.

Mitchell, M. 2009. Complexity: A guided tour. Oxford, UK: Oxford University Press.

Nahapiet, J., \& Ghoshal, S. 1998. Social capital, intellectual capital, and the organizational advantage. Academy of management review, pp. 242-266.

Nattrass, B. \& Altomare, M. 2002. Dancing with the tiger. Gabriola Island, British Columbia, Canada: New Society Publishers.

Nattrass, B. 1999. The Natural Step: corporate learning and innovation for sustainability. Doctoral Thesis. The California Institute of Integral Studies, San Francisco, California, USA.

Nelson, D. R., Adger, W.N. \& Brown, K. 2007. Adaptation to Environmental Change:

Contributions of a Resilience Framework. Annual Review of Environment and Resources. 32, pp.395-419.

Norberg, J. \& Cumming, G.S. 2006. Complexity Theory for a Sustainable Future. Columbia University Press, New York.

Nowotny, H. 2005. The Increase of Complexity and its Reduction: Emergent Interfaces between the Natural Sciences, Humanities and Social Sciences. Theory, Culture \& Society. 22(5):15-31. doi: $10.1177 / 0263276405057189$

Ny H., MacDonald J.P., Broman G., Yamamoto R. \& Robèrt K-H. 2006. Sustainability constraints as system boundaries: an approach to making life-cycle management strategic. Journal of Industrial Ecology. 10(1-2), pp.61-77.

Olsson, P., Folke, C., \& Hahn, T. 2004. Social-ecological transformation for ecosystem management: the development of adaptive co-management of a wetland landscape in southern Sweden. Ecology and Society 9(4):2.

Omann, I. \& Spangenberg, J.H. 2002. Assessing Social Sustainability- The Social Dimension of Sustainability in a Socio-Economic Scenario Presented at the 7th Biennial Conference of the International Society for Ecological Economics in Sousse (Tunisia), 6-9 March 2002 Available at http://seri.at/wp-content/uploads/2010/05/Assessing social sustainability.pdf (Accessed November 29th, 2012)

Osbahr, H., Twyman, C., Adger, W. N. \& Thomas, D. S. G. 2010. Evaluating successful livelihood adaptation to climate variability and change in southern Africa. Ecology and Society. 15(2):27.

Ostrom, E. 2005. Understanding institutional diversity. Princeton, New Jersey, USA: Princeton University Press.

Ostrom, E., \& Ahn, T. K., eds. 2003. Foundations of social capital. Cheltenham, UK: Edward Elgar Publishing.

Ostrom, E., Dietz, T., Dolsak, N., Stern, P., Stonich, S., \& Weber, E.U., eds. 2002. The Drama of the Commons. Washington, DC:Natl. Acad. 
Park, C. 2011. Meaning and Growth within Positive Psychology: Toward a More Complete Understanding. In: Designing Positive Psychology: Taking Stock and Moving Forward. Sheldon, K.M., Kashdan, T.B. \& Steger, M.F. (eds). Cary, NC, USA: Oxford University Press. p- 324 -334.

Park, C. L. 2010. Making sense of the meaning literature: an integrative review of meaning making and its effects on adjustment to stressful life events. Psychological bulletin. 136(2), pp.257-301.

Peffers, K., Tuunanen, T., Rothenberger, M. A., \& Chatterjee, S. 2007. A design science research methodology for information systems research. Journal of management information systems, 24(3), pp. 45-77.

Piketty, T. 2014. Capital in the $21^{\text {st }}$ century. Cambridge, MA, USA: Harvard University Press

Pohl, C., \& Hadorn, G. H. 2007. Principles for designing transdisciplinary research. Munich: Oekom.

Porter, M.E. 1991. Towards a Dynamic Theory of Strategy. Strategic Management Journal. 12(S2):95-117.

Potter, N.N. 2002. How can I be trusted? : a virtue theory of trustworthiness. Lanham, Md.: Rowman \& Littlefield.

Pretty, J. \& Ward, H. 2001. Social capital and the environment. World Development. 29, pp.209227.

Pretty, J. 2003. Social capital and the collective management of resources. Science. 302, pp.1912-1914.

Putnam, R. 1993. Making democracy work. Civic traditions in modern Italy. Princeton (NJ): Princeton University Press.

Putnam, R. 2000. Bowling Alone. The Collapse and Revival of American Community. New York, London: Simon and Schuster.

Ragsdell, G. \& Wilby, J. (eds.). 2001. Understanding complexity. Kluwer Academic/Plenum Publishers

Ramage, M. \& Shipp, K. 2009. Systems Thinkers. London: Springer.

Ramsay, M. 1992. Human needs and the market. Aldershot: Avebury.

Rittel, H.W.J. \& Webber, M.M. 1973. Dilemmas in a general theory of planning. Policy Sciences. 4:155-169.

Robèrt, K.-H. 1994. Den Naturlige Utmaningen (The Natural Challenge). Stockholm, Sweden: Ekerlids Publisher.

Robèrt, K.-H. 1997. ICA/Electrolux - A case report from 1992. 40th CIES Annual Executive Congress, Boston, MA.

Robèrt, K.-H. 2000. Tools and concepts for sustainable development, how do they relate to a general framework for sustainable development, and to each other? Journal of Cleaner Production. 8(3), pp.243-254.

Robèrt, K.-H., Broman, G. \& Basile, G. 2013. Analyzing the concept of planetary boundaries from a strategic sustainability perspective: How does humanity avoid tipping the planet?.Ecology and Society 18(2): 5.

Robèrt, K.-H., Broman, G., Waldron, D., Ny, H., Byggeth, S., Cook, D., Johansson, L., Oldmark, J., Basile, G., Haraldsson, H., MacDonald, J., Moore, B., Connell, T. \& Missimer, M. 2010. Strategic Leadership Towards Sustainability. Karlskrona: Blekinge Institute of Technology. 
Robèrt, K.-H., Schmidt-Bleek, B., Aloisi de Larderel, J., Basile, G., Jansen, J.L., Kuehr, R., Price Thomas, P., Suzuki, M., Hawken, P. \& Wackernagel, M. 2002. Strategic sustainable development selection, design and synergies of applied tools. Journal of Cleaner Production. 10, pp.197-214.

Robèrt K.-H., Borén, S., Nurhadi, L., Broman, G., 2015. A strategic approach to sustainable transport system development - Part 1: attempting a generic community planning process model (in this issue).

Robinson, S. 2006. Issues in conceptual modelling for simulation: setting a research agenda." Proceedings of the 2006 OR Society Simulation Workshop.

Rothstein, B. 2005. Social Traps and the problem of Trust. Cambridge: Cambridge University Press

Rothstein, B. 2007. Anti-Corruption: A" Big-Bang" Theory. Gothenburg: The Quality of Government Institute at University of Gothenburg. Working Paper 2007: 3.

Sawyer, R. K. 2005. Social emergence: Societies as complex systems. Cambridge, UK: Cambridge University Press

Scheffer, M., Westley, F., Brock, W.A. \& Holmgren, M. 2001. Dynamic interaction of societies and ecosystems: Linking theories from ecology, economy, and sociology. In Panarchy: understanding transformations in human and natural systems. Gunderson, L. \& Holling, C.S. (Eds). Island Press, Washington, DC, USA:195-239.

Sen, A. 1992. Inequality Reexamined. Oxford, England: Oxford University Press.

Sen, A. and Nussbaum, M. 1993. The Quality of Life. Oxford, England: Oxford University Press.

Sen, A. 1999. Development as Freedom. Oxford, England: Oxford University Press.

Senge, P. M. 1990. The Fifth Discipline. New York: Broadway Business.

Shrivastava, P., Ivanaj, S., Persson, S., 2013. Transdisciplinary Study of Sustainable Enterprise. Business Strategy and the Environment 22, pp. 230-244.

Spangenberg, J. H. \& Omann, I. 2006. Assessing social sustainability: social sustainability and its multicriteria assessment in a sustainability scenario for Germany. International Journal of Innovation and Sustainable Development. 1(4), pp.318-348.

Stacey, R. D. 2007. Strategic management and organisational dynamics: The challenge of complexity to ways of thinking about organisations. Pearson education

Stichweh, R. 2000. On the Genesis of World Society: Innovations and Mechanisms. Distinktion: Scandinavian Journal of Social Theory. 1(1), pp.27-38.

Strauss-Kahn, D. 2004. Building a Political Europe. 50 Proposals for Tomorrow's Europe. Brussels: European Commission.

Törnberg, A. 2011. Using Complexity Theory Methods for Sociological Theory DevelopmentWith a Case Study on Socio-Technical Transitions. Master's Thesis, Gothenburg University.

United Nations. 2015. Transforming our World: the 2030 agenda for sustainable development. $\mathrm{A} / \mathrm{RES} / 70 / 1$.

Urry, J. 2003. Global Complexity. Cambridge/Oxford, UK: Polity Press

Vaishnavi, V., \& Kuechler, W. 2004. Design research in information systems. Available at http://www.isworld.org/Researchdesign/drisISworld.

Walby, S. 2003, April. Complexity theory, globalisation and diversity. In conference of the British Sociological Association, University of York. 
Walby, S. 2007. Complexity Theory, Systems Theory, and Multiple Intersecting Social Inequalities. Philosophy of the Social Sciences. 37(4):449-470. doi:10.1177/0048393107307663

Waldron, D. 2005. A new education - "strategic leadership towards sustainability". Seminar on education for sustainable development (Seminarium om utbildning för hållbar utveckling), Stockholm, Sweden, Ministry of Culture and Education.

Waldron, D., Byggeth, S., Ny, H., Broman, G., \& Robèrt, K.-H. 2004. Structured comprehension for systems thinking, learning and leadership towards sustainability. Environmental Management for Sustainable Universities (EMSU). Tecnológico de Monterrey, Mexico.

Walker, B., Gunderson, L.H., Kinzig, A., Folke, C., Carpenter, S. \& Schultz, L. 2006. A handful of heuristics and some propositions for understanding resilience in social-ecological systems. Ecology and Society. 11(1):13.

Walker, B., Holling, C.S., Carpenter, S.R. \& Kinzig, A. 2004. Resilience, adaptability and transformability in social-ecological systems. Ecology and Society. 9(2):5.

Wells, G. 2009. The Meaning Makers: Learning to Talk and Talking to Learn (2nd ed) Bristol, Buffalo,Toronto: MULTILINGUAL MATTERS.

Westley, F. 2002. The devil in the dynamics. In Panarchy: understanding transformation in human and natural systems. Gunderson, L. H. \& Holling, C. S., eds. Island Press, Washington, D.C., USA. Pp.333-360.

Westley, F., Goebey, S., \& Robinson, K. 2012. Change lab/design lab for social innovation. Waterloo: Waterloo Institute of Social Innovation and Resilience, University of Waterloo. Availabe at http://www.marsdd.com/wpcontent/uploads/2014/05/Paper_FINAL_LabforSocialInnovation.pdf

Wickson, F., Carew, A. L., \& Russell, A. W. 2006. Transdisciplinary research: characteristics, quandaries and quality. Futures, 38(9), 1046-1059.

Wilkinson, R.G \& Pickett, K. 2009. The Spirit Level. London: Bloomsbury Press.

Wollebaek, D. \& Selle, P. 2008. Where does social capital come from? In The third sector in Europe. Osborne, S.P. (eds) NY, NY: Routledge Studies in the Management of Voluntary and Non-profit Organizations.

World Commission On Environment And Development. 1987. Our Common Future. [report of the ] World Comission on Environment and Development. Available at: http://www.undocuments.net/wced-ocf.htm (Accessed Januray 21st, 2013) 